\title{
Variations in dung beetles assemblages (Coleoptera: Scarabaeidae) within two rain forest habitats in French Guiana
}

\author{
François Feer \\ Muséum National d'Histoire Naturelle, CNRS UMR 7179, 4 avenue du Petit-Château, 91800 Brunoy, France; \\ feer@mnhn.fr
}

Received 12-IV-2012. Corrected 05-IX-2012. Accepted 03-X-2012.

\begin{abstract}
Variaciones de las agregaciones de escarabajos coprófagos (Coleoptera: Scarabaeidae) en dos hábitats del bosque tropical en la Guayana Francesa. The structure of dung beetle communities inhabiting tropical forests are known to be sensitive to many kinds of environmental changes such as microclimate related to vegetation structure. I examined Scarabaeinae assemblages in two sites of undisturbed high forest and two sites of low forest forming a transitional zone with the open habitat of an inselberg in French Guiana. Sampling was made with pitfall and flight interception traps during 2003 and 2004. The driest and warmest conditions characterized the low forest sites. Across two years we obtained 2927 individuals from 61 species with pitfall traps and 1431 individuals from 85 species with flight interception traps. Greater species richness and abundance characterized all sites sampled with pitfall traps during 2003 more than 2004. In 2003 no differences were detected among sites by rarefaction analyses. In 2004 the species richest high forest site was significantly different from one of the low forest sites. For both years Clench model asymptotes for species richness were greater in high forest than in low forest sites. For both years, mean per-trap species richness, abundance and biomass among high forest sites were similar and higher than in low forest sites, especially where the lowest humidity and the highest temperature were recorded. Within the two low forest sites, species richness and abundance recorded during the second year, decreased with distance to edge. Different dominant roller species characterized the pitfall samples in one site of low forest and in other sites. Small variations in microclimatic conditions correlated to canopy height and openness likely affected dung beetle assemblages but soil depth and the presence of large mammals providing dung resource may also play a significant role. Rev. Biol. Trop. 61 (2): 753-768. Epub 2013 June 01.
\end{abstract}

Key words: inselberg, microclimate, trapping methods, Scarabaeinae beetles, species diversity, vegetation structure.

Dung beetles (Coleoptera: Scarabaeidae: Scarabaeinae) constitute rich communities in most terrestrial ecosystems where they provide key ecological functions and services such as nutrient cycling, soil fertilization, biological pest control and secondary seed dispersal (Hanski \& Cambefort 1991, Nichols et al. 2008). Moreover, dung beetles have been considered as a useful indicator group of habitat disturbance particularly in tropical rain forests (Favila \& Halffter 1997, Davis et al. 2001, Larsen 2012). Their community structure is sensitive to many kinds of environmental change and linked with mammal communities (Halffter et al. 1992, Andresen 2005, Andresen \& Laurance 2007, Spector 2006, Nichols et al. 2009). The patterns of response of dung beetles communities have been extensively studied comparing high tropical forest to disturbed forests (reviewed in Nichols et al. 2007) or at sharp habitat ecotones (Hill 1996, Spector \& Ayzama 2003, Feer 2008). Habitat selectivity of dung beetles is regulated by sensitivity of adults and larvae to temperature and hygrometry (Sowig 1995, Duncan \& Byrne 2000). Most of tropical forest species seem to have a narrow 
climatic tolerance. It explains why tropical assemblages show a clear decrease in species richness and abundance when microclimatic conditions went dryer and warmer in disturbed forest. Studies on the distribution of dung beetle species linked to natural environmental gradient into rain forest habitat are scarce (see Davis et al. 2001) although they might be useful to understand changes observed in disturbed ecosystems.

The heterogeneity of forest habitat in Amazonia depends on environmental factors (precipitation, soil fertility, topography) and induces variation of canopy heterogeneity (Barbier et al. 2010). Degree of openness of canopy strongly influences microclimate and soil humidity at ground level as it was observed near forest edges (Didham \& Lawton 1999). Recent data indicate that some neotropical dung beetles species specialize on restricted habitats or microhabitats (Larsen et al. 2006). Consequently community structure may change at local or regional scale depending on the distribution of specific biotopes.

Here, I examined the structure of dung beetles assemblages in two adjacent habitats of the primary forest with distinct features of vegetation structure and microclimate condition. Along an inselberg-rainforest ecotone, I compared tall-tree rainforest to low forest forming a transitional zone with rocky open habitat. I questioned whether the dung beetle assemblages were different in the two habitats. Specifically, I tested the prediction that lower species richness and abundance corresponds to warmer and dryer microclimate. Furthermore I investigated whether change affects species composition and, if so what are the characteristics of the major species involved. Similarity and difference with disturbed forests and anthropogenic forest edges of the same region were discussed.

\section{MATERIALS AND METHODS}

Study site: The work was carried out at the Nouragues Research Station ( $4^{\circ} 5^{\prime} \mathrm{N}-52^{\circ} 40^{\prime}$ W) which lies at $100 \mathrm{~km}$ South of Cayenne,
French Guiana. The station is located in the centre of the Nouragues Natural Reserve $\left(1000 \mathrm{~km}^{2}\right)$ covered by undisturbed evergreen forest (Bongers et al. 2001). The climate is characterized by a long wet season lasting from December to August, often interrupted by a short, drier period around March. Average annual rainfall is $2990 \mathrm{~mm}$ and mean temperature is $26.3^{\circ} \mathrm{C}$ (Grimaldi \& Riéra 2001). The study site is dominated by a partly denuded granitic inselberg which reaches an elevation of $411 \mathrm{~m}$ above sea level. The summit area and the basal gentle slopes termed terrace are characterized by a low xeromorphic rock savannah vegetation (Sarthou 2001). The low forest extends around the outer borders of the rock savannah as a continuous belt, of generally less than a hundred meters wide between the rock savannah and the high forest. Low forest has a canopy height usually situated between 8 and $15 \mathrm{~m}$ and it is rich in shrubs and small trees (Myrtaceae, Rubiaceae, Nyctaginaceae and Erythroxylaceae) with abundant epiphytes and terricolous herbs in the understory (Larpin 2001). From open-rock vegetation to high forest, shallow soil passes from organic-rich sandy cambisols into ferralsols, with increasing depth (Grimaldi \& Riéra 2001). Periodic desiccation of soil occurs during the dry period, especially when it is shallow on the rock and located on steep slope causing a rapid run-off of water.

I selected two low forest areas: one at the foot of the inselberg on a $40 \%$ slope under the South-Eastern rocky terrace (hereafter called T, Fig. 1), and the other one on the Western inselberg ridge (I) situated about $250 \mathrm{~m}$ above T. Referring to the same areas, Sarthou et al. (2001) show that soil depth is higher in I than $\mathrm{T}$ area. High forest area is covered by $30-35 \mathrm{~m}$ high mature forest with open understory. Dominant canopy plant families include Leguminosae, Sapotaceae, Burseraceae, Chrysobalanaceae, Lecythidaceae, Rubiaceae, Vochysiaceae and Nyctaginaceae (Poncy et al. 2001). Soils are ferralsols locally rich in ferruginous nodules near the creek. The Nouragues creek, a tributary of the River Approuague, flows past the foot of the inselberg and, 




Fig. 1. Study area with the different habitats (high forest in white), the sampling sites plateau (P), creek bank (C), inselberg ridge (I) terraces (T) and the situation of the pitfall traps (square and line) and flight interception trap (FIT).

toward East along a gentle slope. I selected two high forest areas: one along the left bank of the creek (C) and another $100 \mathrm{~m}$ above on the flat area of a plateau $(\mathrm{P})$.

A total of 127 mammal species were recorded at the site including 67 non-flying species (Bongers et al. 2001). Large phytophagous species of mammals are providing the bulk of resources for coprophagous dung beetles. Five species of primates are common in high forest but only Cebus apella was occasionally observed in the low forest and rock savannah (F. Bayard personal communication). Tracks of peccaries and agoutis were observed in the low forest area I but not in T. These species are common in high forest where other large terrestrial mammals such as tapir, brocket deers are also present (Feer et al. 2001).

Microclimate: The total rain during the study period was $486 \mathrm{~mm}$ in 2003 and $630 \mathrm{~mm}$ in 2004. Differences in $24 \mathrm{~h}$ average rain between years were not significant (respectively, $15.7 \mathrm{~mm}$ and $20.3 \mathrm{~mm}$, Mann-Whitney test, $\mathrm{p}>0.05$ ). Microclimatic data, air humidity and temperature, were recorded in 2004 with a portable thermo hygrometer in open habitat (rock savannah), low forest (interior and edge) and high forest. Measurements were taken randomly at $0.8 \mathrm{~m}$ high during the most humid and the less warm period of the day (7:00-9:00h) and during the driest and the warmest period (14:00-16:00h) according to data taken along $24 \mathrm{~h}$. Mean values were used to compare habitats.

Sampling method: For insect sampling I used baited pitfall traps made of plastic pots (10 $\mathrm{cm}$ diameter $15 \mathrm{~cm}$ depth), protected from rain. I used human faeces as bait because it remains the best attractant for dung beetles (Howden \& Nealis 1975, Feer 2000). Insects falling into the traps were killed by a solution of water with detergent and sodium chloride. Each trapping session lasted four days and baits were renewed once after $48 \mathrm{~h}$. In both years, ten traps $40 \mathrm{~m}$ distant were arranged along a linear transect in $\mathrm{P}$ along the ridge of the plateau, and in $\mathrm{C}$ at $5-10 \mathrm{~m}$ from the creek. In 2003, five traps were installed in each of the low forest 
areas. The traps were $30 \mathrm{~m}$ distant at a distance from forest edge varying from $30-90 \mathrm{~m}$ in I and $50-120 \mathrm{~m}$ in T. In 2004, three parallel transects of four traps each were installed in each low forest site in order to assess edge effect. The transects were $40 \mathrm{~m}$ distant, oriented perpendicular to the forest limit. The traps were at different distance from edge: $0 \mathrm{~m}$ (under vegetation as close as possible to the forest edge), 30, 60, and $120 \mathrm{~m}$ (approximately corresponding to the limit of the low forest with high forest). At each transect one trap situated in rock savannah under a thicket of Clusia minor L. was associated, at a minimum distance of $40 \mathrm{~m}$ from low forest edge. Dung beetles were sampled from mid April-mid May 2003 and in the same period for 2004, with one trapping session per area and per year.

To obtain complementary data on the species richness, I used ground-based Flight interception traps (FITs). They provide a relatively unbiased sampling method of collecting beetles (Davis 1993, Larsen et al. 2006), as they passively collect insects flying through the forest. FITs were made of a vertical panel of $140 \times 200 \mathrm{~cm}$ plastic mosquito net with trays disposed along its base, filled with a killing and preservative solution. They were set at a minimum distance of $40 \mathrm{~m}$ from the nearest pitfall trap. Each year, one FIT per site was used during a period of 20 days.

I identified species in the laboratory by comparing specimens against collections in the Laboratoire d'écologie (Brunoy) and the Laboratoire d'entomologie of the Muséum National d'Histoire Naturelle (Paris). Some species without corroborative specimens for comparison were classified to the generic level. The voucher specimens of Nouragues were deposited in Brunoy. Only the Scarabaeinae species were considered in the study. Other groups such as Aphodiidae, Hybosoridae, Geotrupidae and Hydrophylidae were rare in the collected material.

Owing to differences in abundance and sampling effort, patterns of species richness among habitats in each year were compared using rarefaction analyses and the Clench model for species-richness estimation. Shannon's diversity index was determined for each sample using EstimateS software (Colwell 2004). To account for variation in species richness among samples, sample-based rarefaction curves were produced using EstimateS software with 100 randomizations. Differences in species richness among assemblages were tested by observing whether the rarefaction curve of the most species poor assemblage lay within the $95 \%$ confidence limits of the rarefaction curve of the most species rich assemblage at the point of equal abundance (Magurran 2004). Non parametric models of estimation of true species richness (Chazdon et al. 1998) failing to give stable values of richness with the data, a parametric model was chosen because it offers the advantage to allow the calculation of an asymptote or estimated limit of the true species richness. The Clench model (Clench 1979) supposes that the probability to find a new species diminishes with the catching effort but remains negligible because of the number of rare species. The number of species was determined following Soberon \& Llorente (1993): S=E $a /(1+b E)$, where $S$ is the number of species and $\mathrm{E}$ the number of individuals which can be assimilated to sampling effort. The degree of adjustment of the model with the data has been estimated by $\mathrm{R}^{2}$ and the completeness in percent is the rate of the maximum number of observed species with the model asymptote $a / b$.

Beetle species richness and abundance in each trap for the total session were determined for each habitat and year. An approximation of biomass was obtained by multiplying the abundance of each species by its average individual length, obtained by measuring a minimum of ten individuals, and summing the results for all the species of the trap. Species richness and abundance were square root transformed, biomass was log transformed and then analysed with a general linear model using SYSTAT 9.0 (SYSTAT 1999). I used two fixed effects, year (two levels) and habitat (four levels) to analyse per-trap species richness, abundance and biomass. The data for trends in dung beetle species richness and abundance in 2004 were 
analysed with respect to the distance to the edge and $\log _{10}$ of that distance. I used the total number of species and individuals obtained per trap on the sampled transect to test for correlation (Spearman rank-order coefficient) with distance to edge.

I tested for differences in species composition in the dung beetle assemblages between habitats, years and trapping methods using data of species abundance per sample. I then generated a data matrix of pairwise comparisons based on the Bray-Curtis similarity using square-root transformed abundances with the software package PRIMER version 6 (Clark \& Gorley 2006). Based on the similarity matrix a multidimensional scaling (MDS) ordination was presented. MDS was chosen over other ordination methods because it makes fewer assumptions about the data distribution, and provide a visually intuitive summary of similarity among samples (Clarke \& Warwick 1994). A one-way analysis of similarity (ANOSIM) was used to test variation in assemblage composition using PRIMER. The $\mathrm{R}_{\text {ANosim }}$ statistic value is a relative measure of separation of the defined groups compared with 999 randomizations to generate probability values. If a grouping factor defined significantly different groups, a one-way ANOSIM analysis was used.

\section{RESULTS}

Microclimate: In the morning, the highest air humidity and the lowest temperature varied in a narrow range in all the areas (respectively, 93.0-95.8\% and $25.4-26.1^{\circ} \mathrm{C}$ ). In the afternoon, high forest $\mathrm{P}$ and $\mathrm{C}$ showed similar conditions with lower humidity and higher temperature than in the morning in 2004 (Fig. 2). In low forest I, humidity was similar than in high forest but temperature was lower. In T, I recorded the lowest humidity (79.5\%) and the highest temperature $\left(29.1^{\circ} \mathrm{C}\right)$. In low forest, little change was recorded from edge to interior in $\mathrm{T}$, whereas more pronounced differences were recorded in I. In adjacent rocky habitat, little change occurred by comparison to I edge whereas a clear increase in temperature and a decrease in humidity prevailed near $\mathrm{T}$.

Species richness and abundance: The total dung beetle sample obtained with pitfall traps comprised 1994 individuals from 55 species in 2003, and 933 individuals from 47 species in 2004 . The complete data set is presented in appendix. The overall raw data showed smaller species richness and abundances in 2003 than in 2004 (Table 1). In both years the smallest values were recorded in site

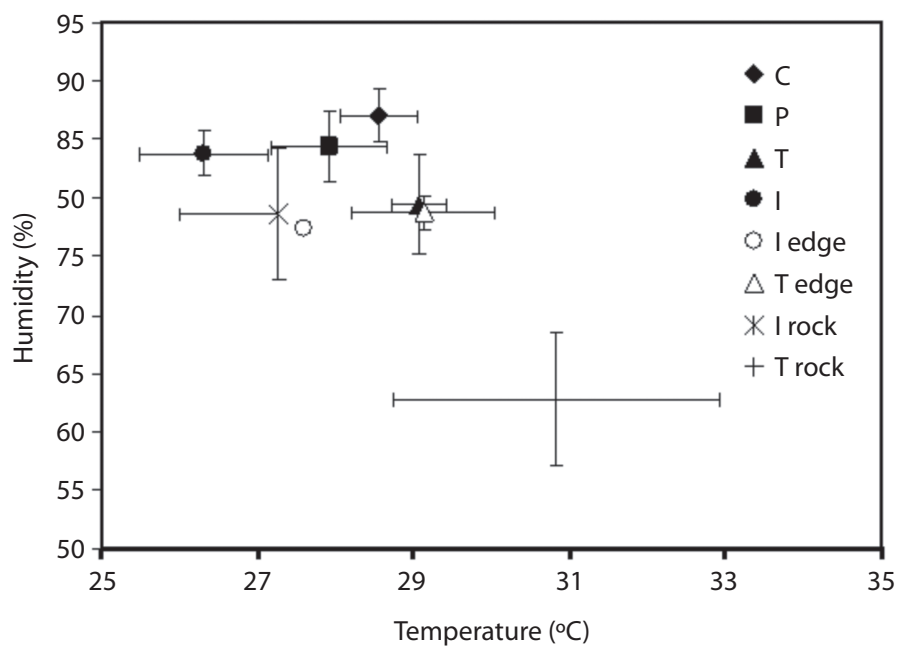

Fig. 2. Microclimatic conditions (mean $\pm S E$ air humidity and temperature between 14:00-16:00h) in high forest, low forest (interior and edge) and open habitat (rock savanna) in 2004. Creek: C; Plateau: P; Inselberg: I; Terrace: T. 
T. In 2003 rarefaction analyses showed greater values of species richness in high forest sites but with complete overlaps between the $95 \%$ confidence intervals (Fig. 3, Table 1). In 2004, the values in high forest sites were higher than in I with no overlap of intervals with $\mathrm{C}$. The values of the asymptote of Clench equation are supposed to give a better estimation of the species richness but their validity depends on the completeness. In both years, species richness (Clench) was maximum for $\mathrm{C}$ and minimum for $\mathrm{T}$ but it is worth noting that in 2004 the completeness was low for $\mathrm{T}$ (Table 1).

The results of the ANOVA for the effects of habitat and year on per-trap species richness, abundance and biomass are summarized in table 2. They showed a significant effect of habitat and year without interaction. Larger values of the variables were observed in 2003 than in 2004 (Fig. 4). All the differences within habitats were significant ( $\mathrm{p}<0.05$, Tukey's HSD tests) except for C. No significant differences were recorded for all variables between high forest $\mathrm{P}$ and $\mathrm{C}$. For all variables, smaller values were observed in $\mathrm{T}$ than in one or two of the high forest sites $(\mathrm{p}<0.05)$. The mean number of species richness in $\mathrm{I}$ was higher than in $\mathrm{T}$ in
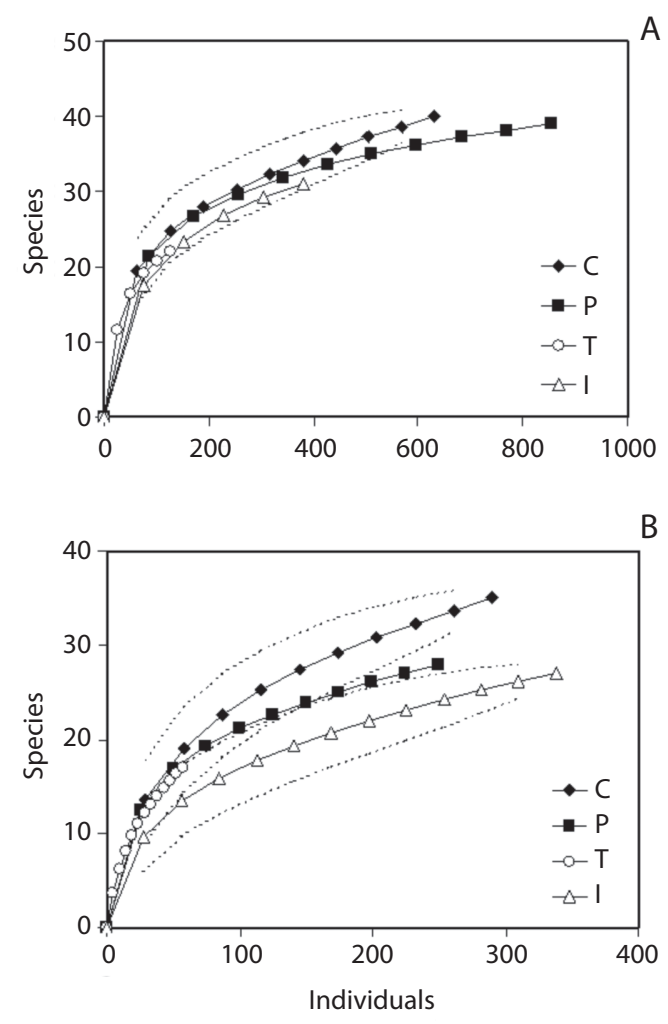

Fig. 3. Sample-based rarefaction curves in (A) 2003 and (B) 2004. The dotted lines indicate the $95 \%$ confidence interval for $\mathrm{C}$ in 2003 and $\mathrm{C}$ and $\mathrm{I}$ in 2004.

TABLE 1

Abundance, species richness and diversity (Shannon H') of dung beetles collected in pitfall traps during two years in four forest sites in the Nouragues Natural Reserve. Rarefaction and the asymptote of Clench model with completeness in percent

\begin{tabular}{|c|c|c|c|c|}
\hline & Creek & Plateau & Inselberg & Terrace \\
\hline \multicolumn{5}{|l|}{ Year 2003} \\
\hline Number of individuals & 632 & 854 & 381 & 127 \\
\hline Number of species & 40 & 39 & 31 & 22 \\
\hline H' (Shannon) & 2.79 & 2.84 & 2.23 & 2.52 \\
\hline Rarefaction $\pm 95 \% \mathrm{CI}$ & $24.9 \pm 4.0$ & $24.4 \pm 4.0$ & $21.8 \pm 3.9$ & 22 \\
\hline Clench (asymptote) ${ }^{\mathrm{a}}$ & 46.0 & 43.1 & 40.6 & 29.2 \\
\hline Completeness $(\%)$ & 87.0 & 90.5 & 76.4 & 75.2 \\
\hline \multicolumn{5}{|l|}{ Year 2004} \\
\hline Number of individuals & 290 & 249 & 337 & 57 \\
\hline Number of species & 35 & 28 & 26 & 17 \\
\hline H' (Shannon) & 2.83 & 2.78 & 2.02 & 2.37 \\
\hline Rarefaction $\pm 95 \% \mathrm{CI}$ & $18.9 \pm 4.0$ & $17.7 \pm 3.4$ & $13.4 \pm 3.5$ & 17 \\
\hline Clench (asymptote) ${ }^{\mathrm{b}}$ & 45.1 & 37.8 & 35.0 & 28.4 \\
\hline Completeness (\%) & 77.7 & 74.1 & 74.2 & 59.9 \\
\hline
\end{tabular}

a. $\quad \mathrm{R}^{2} \geq 0.98 . \quad$ b. $\quad \mathrm{R}^{2} \geq 0.99$. 
TABLE 2

Results of ANOVA of the effects of year (2003 vs 2004) and site $(\mathrm{C}, \mathrm{P}, \mathrm{I}$ and $\mathrm{T})$ on per-trap species richness, abundance and biomass of dung beetles in the Nouragues Natural Reserve

\begin{tabular}{llccc} 
Dependent variable & \multicolumn{1}{c}{ Factor } & F value & D.F. & \multicolumn{1}{c}{$\mathrm{p}$} \\
Per-trap species & Year & 68.58 & 1 & $<0.001$ \\
richness & Site & 21.05 & 3 & $<0.001$ \\
& Year x Site & 1.82 & 3 & 0.15 \\
Per-trap abundance & Year & 64.50 & 1 & $<0.001$ \\
& Site & 13.88 & 3 & $<0.001$ \\
& Year x Site & 1.00 & 3 & 0.40 \\
Biomass & Year & 27.72 & 1 & $<0.001$ \\
& Site & 10.57 & 3 & $<0.001$ \\
& Year x Site & 1.07 & 3 & 0.21 \\
\hline
\end{tabular}

2004. In both years, mean abundance and biomass in I were larger than in $\mathrm{T}(\mathrm{p}<0.01)$.

The total sample obtained by FIT comprised 1060 individuals from 83 species in 2003 and 371 individuals from 64 species in 2004. A total of 15 species were exclusive to FIT $(15.6 \%$ of total species collected, $n=96)$. In 2003, the raw species richness and rarefied values in $\mathrm{C}$ and $\mathrm{P}$ were higher than in $\mathrm{T}$ and I (Table 3). In 2004, the raw species richness was maximum in I and minimum in T but considering the confidence intervals there was no differences in rarefied values between areas.

Species composition: The MDS ordination indicated that FIT samples and pitfall samples were well segregated (Fig. 5). The total FIT sample had more exclusive species $(42.3 \%, \mathrm{n}=85)$ representing a larger proportion of the total number of individuals (19.8\%) than in the total pitfall trap sample (respectively, $19.7 \%$ and $1.9 \%$ ). Analysis of similarity determined that there were significant differences among trapping method $\left(\mathrm{R}_{\text {ANosIM }}=0.686\right.$, $\mathrm{p}=0.002$ ) but not among site or year (respectively $\mathrm{R}_{\text {ANosIM }}=0.112, \mathrm{p}=0.15$ and $\mathrm{R}_{\text {ANosIM }}=0.057$, $\mathrm{p}=0.21$ ). The MDS ordination suggested a segregation within the pitfall trap sample between
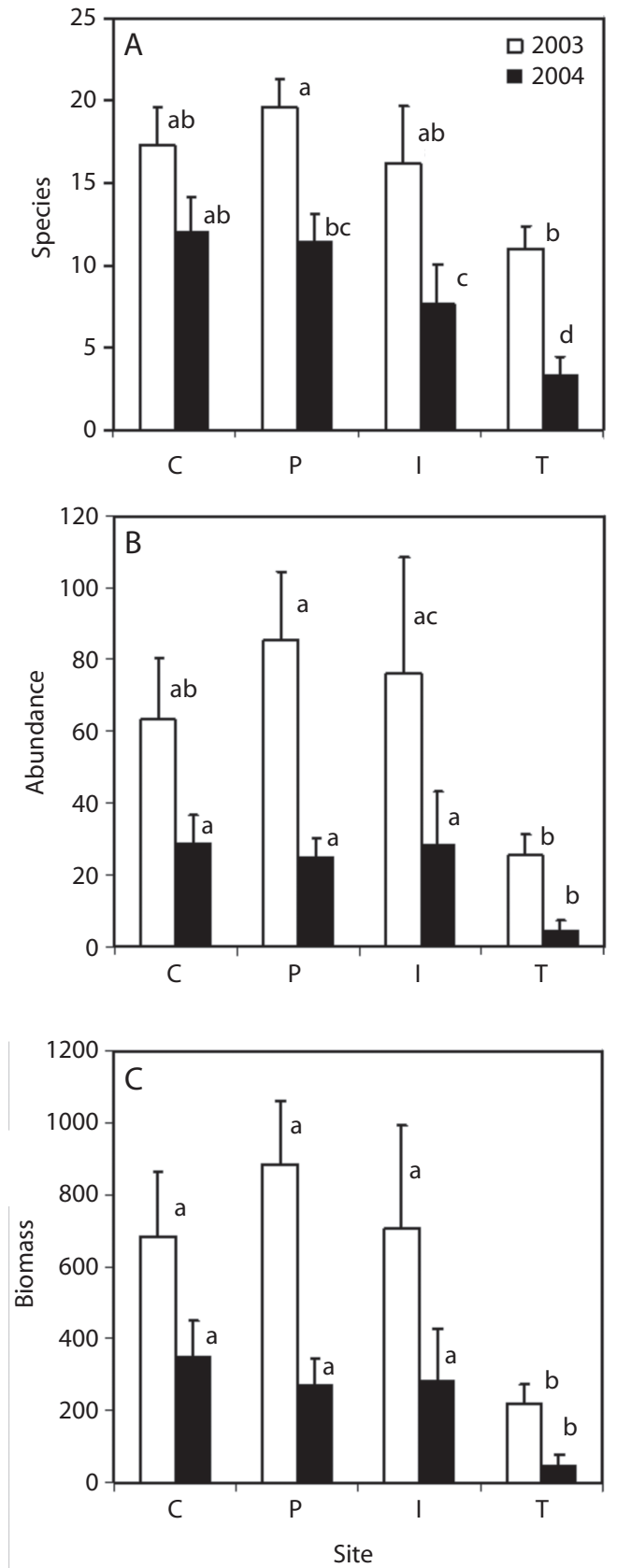

Fig. 4. Mean number of dung beetles species (A), mean abundance (B) and mean biomass per trap (C) in the four sites. One letter in common means non significant difference $(\mathrm{p}>0.05)$ of post-hoc analyses within years. 
TABLE 3

Abundance, species richness and rarefaction of dung beetles collected in FITs during two years in four sites in the Nouragues Natural Reserve

\begin{tabular}{|c|c|c|c|c|}
\hline & Creek & Plateau & Inselberg & Terrace \\
\hline \multicolumn{5}{|l|}{ Year 2003} \\
\hline Number of individuals & 232 & 292 & 307 & 229 \\
\hline Number of species & 52 & 53 & 41 & 43 \\
\hline Rarefaction $\pm 95 \% \mathrm{CI}$ & $51.8 \pm 0.8$ & $49.4 \pm 3.2$ & $37.7 \pm 3.0$ & 43 \\
\hline \multicolumn{5}{|l|}{ Year 2004} \\
\hline Number of individuals & 123 & 94 & 123 & 31 \\
\hline Number of species & 34 & 28 & 35 & 20 \\
\hline Rarefaction $\pm 95 \% \mathrm{CI}$ & $16.4 \pm 3.9$ & $14.9 \pm 3.7$ & $17.2 \pm 3.8$ & 20 \\
\hline
\end{tabular}

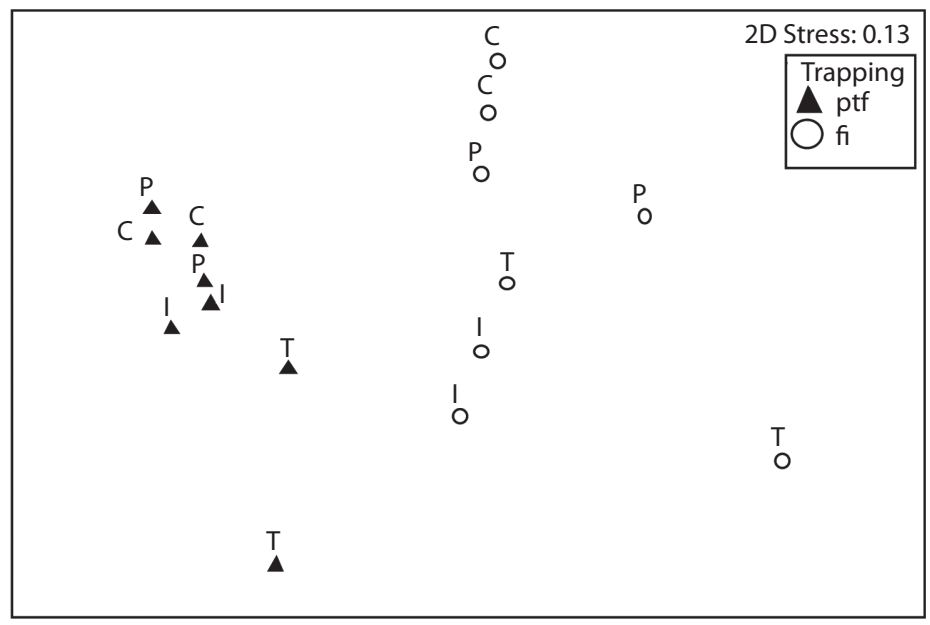

Fig. 5. Nonmetric multidimensional scaling ordination showing differences in the samples composition among the four sites based on the Bray-Curtis similarity index. Open circles indicate FIT samples (fit) and black triangles pitfall trap samples (ptf). Year 2003 is indicated by (3) and year 2004 by (4). A stress value of 0.13 indicates a satisfying 2D representation.

high forest sites, site I and site T. Analyses determined that there were significant differences among sites within the pitfall trap samples $\left(\mathrm{R}_{\mathrm{ANOSIM}}=0.625, \mathrm{p}=0.019\right)$ but pairwise comparisons were not possible because of the small number of replicates.

In both years, Hansreia affinis (Fabricius 1801) ranked first to third in $C$ and $P$ pitfall samples with more than $10 \%$ of total individuals (Appendix). It ranked first in I $(43.0 \%$ in 2003 and $50.7 \%$ in 2004). Another roller species, Trichocanthon sordidus Harold 1868, was dominant in T, ranking second in 2003 and first in 2004 (respectively $22.0 \%$ and $29.8 \%$ ). The following species in terms of abundance was Onthophagus rubrescens Blanchard 1843 ranking second and third in $\mathrm{C}, \mathrm{P}$ and I respectively in 2003 and 2004. Other relatively abundant species during both years were Ateuchus sp. aff. murrayi (Harold 1868) in I and T, Canthon bicolor Castelnau 1840 in $\mathrm{P}$ and Oxysternon festivum (Linné 1767) in C.

In 2003, Ateuchus sp. 1 ranked first and second in all FIT samples with more than $11 \%$ of total individuals. Other high ranking species were Deltochilum guyanense Paulian 1933 (C), Dichotomius lucasi (Harold 1869) (I) and Ateuchus simplex (Audinet-Serville 1828) 
(T). In 2004, Ateuchus sp. 1 and D. guyanense had similar high rank in $\mathrm{P}$ and $\mathrm{C}$ (respectively $17.0 \%$ and $24.0 \%$ ). Other high ranking species were $A$. sp aff. murrayi and $T$. sordidus in $\mathrm{I}$ and $\mathrm{T}$.

Edge effect: Species richness and abundances in $\mathrm{I}$ and $\mathrm{T}$ decreased toward forest edge and were significantly correlated to the distance to edge (Fig. 6) (respectively species, Spearman $\mathrm{r}=0.93, \mathrm{p}<0.001$, and $\mathrm{r}=0.80$, $\mathrm{p}<0.001$; abundance, $\mathrm{r}=1.00, \mathrm{p}<0.001$, and $\mathrm{r}=0.75, \mathrm{p}<0.01)$. In $\mathrm{T}$, species richness and abundance at $120 \mathrm{~m}$ from edge were smaller than in $\mathrm{C}$ and $\mathrm{P}$ (Mann-Whitney test, $\mathrm{p}<0.05$ ).

A
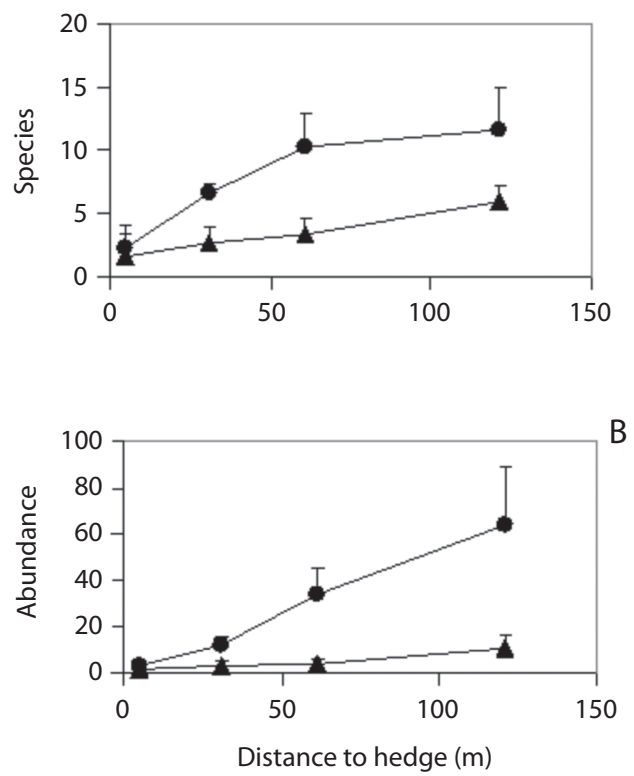

Fig. 6. Dung beetle species richness (A) and abundance (B) responses $( \pm \mathrm{CI})$ to the distance to the forest edge in low forest T (triangle) and I (circle) in 2004.

In $\mathrm{I}$, species richness at $120 \mathrm{~m}$ from edge was not significantly different from $\mathrm{C}$ and $\mathrm{P}$ whereas abundance was larger than in $\mathrm{C}$ and $\mathrm{P}$ $(\mathrm{p}<0.05)$. In rock savannah habitat, no insects had been trapped near $\mathrm{T}$ whereas three individuals of Canthon triangularis (Drury 1770) were present near I. Five individuals of this species were also collected along the I edge of low forest but it was absent in $\mathrm{T}$.

\section{DISCUSSION}

The trends observed in 2003 with pitfall trapping became more pronounced in 2004 with greater species richness in one of the high forest sites compared to low forest sites. Considering the Clench model estimation and the per-trap means, low forest site I showed intermediate values between high forest sites and T. Similarly FIT data showed higher species richness in high forest than in low forest in 2003. In 2004 however, it was not possible to differentiate the habitats because of the low capture level, especially in $\mathrm{T}$.

The overall trend was a decrease in species richness and abundance where conditions near the ground where dung beetles are active went drier and warmer. It is clear in T but less in I where conditions are closer to high forest. Frequent occurrence of mist covering the top of the inselberg (F. Feer, personal observation) may have buffered the effect of low canopy. Similar conditions prevailed in the two high forest sites but, consistently with Cockle's (2001) measures, conditions near the creek were wetter than on the plateau. A trend toward a richer assemblage in $\mathrm{C}$ suggests that a small increase in humidity may have an effect. More pronounced contrasts between high forest habitats is to be expected in the dry season.

Dung beetle communities that are closely associated with tropical forest habitats are mostly composed of species sensitive to variations in temperature and humidity depending on the physical structure of the forest, i.e. canopy height and openness. Assemblages display graded responses across the modification gradient from intact tropical forest to clear-cut areas and as habitat fragmentation increases (reviewed in Nichols et al. 2007, Gardner et al. 2008). Here less contrasted patterns were observed except along edges in low forest, where rapid decrease occurred toward the limit with rock savannah as in other forest habitat ecotones (Hill 1996, Spector \& Ayzama 2003, Feer 2008). The more abrupt adverse effect of edge in I than in $\mathrm{T}$ may be related to the higher change in conditions from interior to 
edge in I. Most likely the edge effect penetrated more deeply into low forest in $\mathrm{T}$ and possibly farther in the adjacent high forest because of the slope. Dung beetles are thus fine indicator group reflecting small architectural differences between habitat types (Halffter \& Matthews 1966, Favila \& Halffter 1997, Halffter \& Arellano 2002). Thus they differ from insect that reflect floristic differences (i.e. species composition, biotic) through biotope fidelity via plant-feeding specializations (e.g. moths and butterflies).

Two other factors, one abiotic and another biotic may have played a role here. The nature of soil is known to influence dung burial activity (Osberg et al. 1993). Shallow rocky soils with highly variable moisture in low forest areas may be less favourable than deep high forest soils with a more constant humidity. This must be particularly influential in slope site like T. Like in various tropical and temperate systems, most of the dung beetles sampled in this study use primarily mammal dung (Feer 2000) as an adult and larvae food resource (Hanski \& Cambefort 1991). While there has been few studies on the changes following mammal reduction in otherwise undisturbed tropical forests (but see Andresen \& Laurance 2007), multiple evidence indicate that decline of medium and large bodied mammal faunas can severely disrupt the diversity and abundance of dung beetle communities through alteration of dung resource (reviewed in Nichols et al. 2009). Few large mammals ranged into low forest making this habitat poorer in dung resource than high forest. Cues of terrestrial large mammals presence in I may explain, together with more favourable climatic conditions, an intermediate attractiveness between $\mathrm{T}$ and high forest areas.

Two small roller dung beetles were dominant in pitfall samples ( $\geq 5 \%$ of total). Hansreia affinis characterized C, P and I areas, whereas Trichocanthon sordidus ranked first in T. In the FIT samples, a different ranking was observed: $H$. affinis was rare or absent and T. sordidus was among dominant species in $\mathrm{P}$ and $\mathrm{T}$ in 2003 and in I and T in 2004. Similar trends in these two species were observed in high forest in Nouragues area in a large sample trapped with human faeces and in a FIT sample collected during five years (F. Feer, unpublished). These differences may be partly interpreted in the light of the bias introduced by the trapping method: $H$. affinis is coprophagous (Feer 2000) preferentially captured with dung baited traps whereas $T$. sordidus is a generalist (coprophagous-necrophagous). The high relative abundances obtained for $T$. sordidus in $\mathrm{T}$ with both methods may result from a higher ecological tolerance to dry and warm conditions. Consistently, studying the responses of dung beetles to rain forest edge in Paracou (French Guiana), Feer (2008) showed that $H$. affinis is negatively affected by edge, whereas T. sordidus is not affected. In forest-savanna mosaic in Ivory Coast, Krell et al. (2003) have shown that rollers are competitively dominant on tunnellers but they need high temperatures. Perching behaviour, observed with all diurnal small rollers $(<10 \mathrm{~mm}$ body size) of the study area (F. Feer, personal observation), is known to have a role in thermoregulation and high body temperature may be related to competitive dominance in neotropical dung beetles (Young 1984). Large tunnelers foraging on larger dung deposition (Peck \& Howden 1984, Gill 1991) need deeper soil than rollers and are disadvantaged by high maximum temperatures (Batholomew \& Heinrich 1978). Such ecological needs and physiological constraints may explain why some large species $(\geq 10 \mathrm{~mm}$ body size) of Phanaenini (Oxysternon and Phanaeus spp.) or Dichotomius spp. were more frequently captured with pitfall trap in high forest than in low forest. Similar trends appeared in FIT for these genera but it was not the case for Coprophanaeus spp., including the largest species Coprophanaeus lancifer (Linné 1767). Specific traits associated with sensitivity to warm and dry conditions are still to be studied. Here we witnessed an overall impoverishment of forest specialists fauna when conditions change rather than an emergence of an original fauna.

C. triangularis had never been trapped in high forest in Nouragues in this study as well as in the past trapping sessions. It occurred only 
along the edge of low forest I. It was also present in riverine forest along the nearby Arataye river and in low forest in Kaw ridge, French Guiana (F. Feer, personal observation). It is one of the rare species positively affected by edge in Paracou disturbed forest (Feer 2008). Canthon triangularis was a dominant species among the assemblage of dung beetles in a fragment of high forest with depauperate mammal fauna near Cayenne (F. Feer, unpublished). This species can be considered as tolerant to forest disturbance (climatic conditions and resource) but it seems to be abundant only where deep forest dung beetle fauna is severely reduced.

Although few sites were inventoried, this study showed that dung beetle assemblage are sensitive to small scale variations of environmental conditions into primary forest. Abiotic factors were likely involved but biotic factors such as the abundance of mammals may also play a role (Nichols et al. 2009). We need replicates on a larger scale and to investigate other natural habitat types such as riverine lowland cloud forest (Obregon et al. 2011), bamboo forest or palm swamp to understand the effects of natural forest dynamics and by extension of anthropogenic disturbance on species distribution. A regular increase in temperature observed over the last 50 years in French Guiana was the most probable cause of plant species richness 10-year decrease in low forest in Nouragues (Fonty et al. 2009). Similar trends are predicted in several region of South America (Boulanger et al. 2006) which may play direct or indirect role on dung beetle communities through changes in forest structure.

\section{ACKNOWLEDGMENTS}

I thank Philippe Gaucher, Patrick Châtelet and the staff of the Nouragues Research Station (CNRS, French Guiana), for commodities and technical help during the field session. I thank the anonymous reviewers for helping to clarify this manuscript; and I. Mendoza for providing a Spanish translation of the abstract. Financial support was given by the Muséum National d'Histoire Naturelle (Paris, France) and the CNRS (UMR 7179), which are gratefully acknowledged.

\section{RESUMEN}

Es conocido que la estructura de las comunidades de escarabajos coprófagos que habitan los bosques tropicales es sensible a diferentes tipos de cambios ambientales tales como el microclima asociado a la vegetación. Hemos examinado las comunidades de Scarabaeinae en dos parcelas de bosque alto sin perturbación y en dos parcelas de bosque bajo, presentes en la transición con el hábitat abierto de un inselberg en la Guayana francesa. Las parcelas de bosque bajo tienen condiciones climáticas más cálidas y secas. A lo largo de dos años, mediante trampas de caída con atrayente, capturamos un total 2927 individuos de 61 especies y con trampas de intercesión de vuelo, un total de 1431 individuos pertenecientes a 85 especies. Una mayor riqueza específica y abundancia caracteriza a todos los sitios de muestreo con trampas de caída en 2003 más que en 2004. En el 2003 no se detectaron diferencias entre los sitios de análisis de rarefacción. En el 2004 la riqueza de especies fue significativamente diferente en el bosque de altura que en el bajo. Durante los dos años, las asíntotas del modelo de Clench para la riqueza específica fueron mayores en bosque alto que en bosque bajo. Durante los dos años, el promedio por trampa de riqueza específica, abundancia y biomasa fueron similares entre las parcelas de bosque alto, pero mayores que en las parcelas de bosque bajo, especialmente en los sitios en los que se registró una mayor temperatura y menor humedad. Dentro de las dos parcelas de bosque bajo, la riqueza específica y la abundancia durante el segundo año disminuyeron con la distancia al borde. Las especies de coprófagos rodador que dominaban una de las parcelas del bosque bajo eran distintas de la del resto de parcelas. Los resultados de este estudio muestran que las pequeñas variaciones en las condiciones microclimáticas que están correlacionadas con la altura y la apertura del dosel arbóreo probablemente afectan a las comunidades de escarabajos coprófagos, aunque también son importantes la presencia de un suelo profundo y de grandes mamíferos que proporcionan recursos con sus heces.

Palabras clave: diversidad específica, estructura de la vegetación, inselberg, métodos de captura, microclima, Scarabaeinae, escarabajos.

\section{REFERENCES}

Andresen, E. \& S.G.W. Laurance. 2007. Possible indirect effects of mammal hunting on dung beetle assemblages in Panama. Biotropica 39: 141-146.

Andresen, E. 2005. Effects of season and vegetation type on community organization of dung beetles in a tropical dry forest. Biotropica 37: 291-300. 
Barbier, N., P. Couteron, C.Proisy, Y. Malhi \& J.P. Gastellu-Etchegarry. 2010. The variation of apparent crown size and canopy heterogeneity across lowland Amazonian forests. Global Ecol. Biogeo. 19: 72-84.

Bartholomew, G.A. \& B. Heinrich. 1978. Endothermy in african dung beetle during flight, ball making and ball rolling. J. Exp. Biol. 73: 65-83.

Bongers, F., P. Charles-Dominique, P.M Forget \& M. Théry. 2001. Nouragues: Dynamics and Plant-Animal Interactions in a Neotropical Rainforest. Kluwer, Dordrecht, The Netherlands.

Boulanger, J.P., F. Martinez \& F.C. Segura. 2006. Projection of future climate change conditions using IPCC simulations, neural networks and Bayesian Statistics. I. Temperature mean state and seasonal cycle in South America. Climate Dynamics 27: 233-259.

Chazdon, R.L., J.S. Colwell, J.S. Denslow \& M.R Guariguata. 1998. Statistical methods for estimating species richness of woody regeneration in primary and secondary rain forests of NE Costa Rica, p. 285309. In F. Dallmeier \& J.A. Comiskey (eds.). Forest biodiversity research, monitoring and modelling: conceptual background and Old World case studies. Parthenon Publishing, Paris, France.

Clarke, K.R. \& R.N. Gorley. 2006. PRIMER v6: user manual/tutorial. PRIMER-E, Plymouth, England.

Clarke, K.R. \& R.M. Warwick. 1994. Change in marine communities: an approach to statistical analysis and interpretation. Plymouth Marine Laboratory, Plymouth, England.

Clench, H. 1979. How to make regional lists of butterflies: some thoughts. J. Lepid. Soc. 33: 216-231.

Cockle, A. 2001. The dispersal and recruitment of Cyclanthaceae and Philodendron (Araceae) understorey root-climbing vines, p. 251-263. In F. Bongers, P. Charles-Dominique, P.M. Forget \& M. Théry (eds.). Nouragues: Dynamics and Plant-Animal Interactions in a Neotropical Rainforest. Kluwer, Dordrecht, The Netherlands.

Colwell, R.K. 2004. EstimateS: statistical estimation of species richness and shared species from samples. Version 7. User's guide and application. http://viceroy.eeb.uconn.edu/estimates.

Davis, A.J. 1993. The ecology and behaviour of rainforest dung beetles in Northern Borneo. Ph.D. Thesis, University of Leeds, England.

Davis, A.J., J.D. Holloway, H. Huijbregts, J. Krikken, A.H. Kirk-Spriggs \& S.L. Sutton. 2001. Dung beetles as indicators of change in the forests of northern Borneo. J. Appl. Ecol. 38: 593-616.

Didham, R.R., J.H. Lawton. 1999. Edge structure determines the magnitude of changes in microclimate and vegetation structure in tropical fragments. Biotropica 31: 17-30.
Duncan, F.D. \& M.J. Byrne. 2000. Discontinuous gas exchange in dung beetles: patterns and ecological implications. Oecologia 122: 452-458.

Favila, M.E. \& G. Halffter. 1997. The use of indicator groups for measuring biodiversity as related to community structure and function. Acta Zool. Mex. 72: $1-25$.

Feer, F. 2000. Les coléoptères coprophages et nécrophages (Scarabaeidae s. str. et Aphodiidae) de la forêt de Guyane française: composition spécifique et structure des peuplements. Ann. Soc. Entomol. France 36: 119-145.

Feer, F. 2008. Responses of dung beetle assemblages to characteristics of rain forest edges. Ecotropica 14: 49-62.

Feer, F., C. Julliot, B. Simmen, P.M. Forget, F. Bayart \& S. Chauvet. 2001. La régénération, un processus multi-étape au résultat imprévisible: l'exemple d'une Sapotaceae en forêt de Guyane francaise. Rev. Ecol. (Terre Vie) 56: 119-145.

Fonty, E., C. Sarthou, D. Larpin \& J.F. Ponge. 2009. A 10-year decrease in plant species richness on a neotropical inselberg: detrimental effects of global warming? Glob. Chang. Biol. 15: 2360-2374.

Gardner, T.A., M.I.M. Hernandez, J. Barlow \& C.A. Peres. 2008. Understanding the biodiversity consequences of habitat change: the value of secondary and plantation forests for neotropical dung beetles. J. Anim. Ecol. 45: 883-893.

Gill, B. 1991. Dung beetles in tropical American forests, p. 211-229. In I. Hanski \& Y. Cambefort (eds.). Dung beetle ecology. Princeton University, Princeton, New Jersey, USA.

Grimaldi, M. \& B. Riéra. 2001. Geography and climate, p. 9-18. In F. Bongers, P. Charles-Dominique, P.M. Forget \& M. Théry (eds.). Nouragues: Dynamics and Plant-Animal Interactions in a Neotropical Rainforest. Kluwer, Dordrecht, The Netherlands.

Halffter, G. \& L. Arellano. 2002. Response of dung beetle diversity to human-induced changes in a tropical landscape. Biotropica 34: 144-154.

Halffter, G. \& E.G. Matthews. 1966. The natural history of dung beetles of the subfamily Scarabaeinae (Coleoptera, Scarabaeidae). Fol. Entomol. Mex. 12-14: 1-312.

Halffter, G., M.E. Favila \& V. Halffter. 1992. A comparative study of the structure of the scarab guild in Mexican tropical rain forest and derived ecosystems. Fol. Entomol. Mex. 84: 131-156.

Hanski, I. \& Y. Cambefort. 1991. Dung beetle ecology. Princeton University, Princeton, New Jersey, USA.

Hill, C.J. 1996. Habitat specificity and food preferences of an assemblage of tropical Australian dung beetles. J. Trop. Ecol. 12: 449-460. 
Howden, H.F. \& V.G. Nealis. 1975. Effects of clearing in a tropical rain forest on the composition of the coprophagous scarab beetle fauna (Coleoptera). Biotropica 7: 77-85

Krell, F.T., S. Krell-Westerwalbesloh, I. Weiss, P. Eggleton \& K.E. Linsenmair. 2003. Spatial separation of Afrotropical dung beetle guilds: a trade-off between competitive superiority and energetic constraints (Coleoptera: Scarabaeidae). Ecography 26: 210-222.

Larpin, D. 2001. The low forest (Nouragues Inselberg), p. 47-63. In F. Bongers, P. Charles-Dominique, P.M. Forget \& M. Théry (eds.). Nouragues: Dynamics and Plant-Animal Interactions in a Neotropical Rainforest. Kluwer, Dordrecht, The Netherlands.

Larsen, T.H. 2012. Upslope rage shifts of Andean dung beetles in response to deforestation: compounding and confounding effects of microclimatic change. Biotropica 44: 82-89.

Larsen, T.H., A. Lopera \& A. Forsyth. 2006. Extreme trophic and habitat specialization by Peruvian dung beetles (Coleoptera: Scarabaeidae: Scarabaeinae). Coleopt. Bull. 60: 315-324.

Magurran, A.E. 2004. Measuring biological diversity. Blackwell, Oxford, England.

Nichols, E., S. Spector, J. Louzada, T. Larsen, S. Amezquita \& M. Favila. The Sarabaeinae Research Network. 2008. Ecological functions and ecosystem services of Scarabaeine dung beetles. Biol. Conserv. 141: 1461-1474.

Nichols, E., T. Larsen, S. Spector, A.L. Davis, F. Escobar, M. Favila, K. Vulinec \& The Sarabaeinae Research Network. 2007. Global dung beetle response to tropical forest modification and fragmentation: a quantitative literature review and meta-analysis. Biol. Conserv. 137: 1-19.

Nichols, E., T.A. Gardner, C.A. Peres \& S. Spector. The Sarabaeinae Research Network. 2009. Co-declining mammals and dung beetles: an impending ecological cascade. Oikos 118: 481-487.

Obregon, A., C. Gehrig-Downie, S. Robbert Gradstein, R. Rollenbeck \& J. Bendix. 2011. Canopy level fog occurrence in a tropical lowland forest of French
Guiana as a prerequisite for high epiphyte diversity. Agr. Meteorol. 151: 290-300.

Osberg, D.C., B.M. Doube \& S.A. Hanrahan. 1993. Habitat specificity in African dung beetles: the effect of soil type on dung burial by two species of ball-rolling dung beetles (Coleoptera Scarabaeidae). Trop. Zool. 6: 243-251

Peck, S.B. \& H.F. Howden. 1984. Response of a dung beetle guild to different sizes of dung bait in a Panamanian rainforest. Biotropica 16: 235-238.

Poncy, O., D. Sabatier, M.F. Prévost \& I. Hardy. 2001. The lowland high rainforest: structure and tree species diversity, p. 31-46. In F. Bongers, P. Charles-Dominique, P.M. Forget \& M. Théry (eds.). Nouragues: Dynamics and Plant-Animal Interactions in a Neotropical Rainforest. Kluwer, Dordrecht, The Netherlands.

Sarthou, C. 2001. Plant communities on a granitic outcrop, p. 65-78. In F. Bongers, P. Charles-Dominique, P.M. Forget \& M. Théry (eds.). Nouragues: Dynamics and Plant-Animal Interactions in a Neotropical Rainforest. Kluwer, Dordrecht, The Netherlands.

Soberon, J.M. \& J.B. Llorente 1993. The use of species accumulation functions for the prediction of species richness. Cons. Biol. 7: 480-488.

Sowig, P. 1995. Habitat selection and offspring survival rate in three paracoprid dung beetles: influence of soil type and soil moisture. Ecography 18: 147-154.

Spector, S. \& S. Ayzama. 2003. Rapid turnover and edge effects in dung beetle assemblages (Scarabaeidae) at a Bolivian Neotropical forest-savanna ecotone. Biotropica 35: 394-404.

Spector, S. 2006. Scarabaeine dung beetles (Coleoptera: Scarabaeidae: Scarabaeinae): an invertebrate focal taxon for biodiversity research and conservation. Col. Bull. 5: 71-83.

SYSTAT. 1999. SYSTAT version 0.9 for Windows. SPSS, Chicago, Illinois, USA.

Young, O.P. 1984. Perching of neotropical dung beetles on leaf surfaces: an example of behavioral thermoregulation? Biotropica 16: 324-327. 


\section{APPENDIX}

List of the dung beetle species collected in pitfall traps and FITs in four sites in Nouragues Natural Reserve. Species with abundance $\geq 5 \%$ of total sample are underlined. Creek: C, Plateau: P, Inselberg: I, Terrace: T.

\section{Species}

Agamopus castaneus Balthasar ${ }^{\circ}$ Anomiopus aff. genieri Canhedo* Anomiopus aff. globosus Canhedo Anomiopus aff. lacordairei Waterhouse* Anomiopus aff. parallelus (Harold)* Anomiopus aff. howdeni Canhedo* Ateuchus aff. aeneomicans (Harold)* Ateuchus aff. murrayi (Harold) Ateuchus aff. sulcicolle Harold Ateuchus simplex (Audinet-Serville) Ateuchus sp. 1

Ateuchus sp. 2

Ateuchus sp. 3

Ateuchus substriatus (Harold)

Bdelyrus aff. geijkeisi Huijbregts*

Bdelyrus aff. seminudum Bates*

Canthidium aterrimum Harold

Canthidium aurichalceum Preudhomme de Borre*

Canthidium bicolor Boucomont*

Canthidium centrale Boucomont

Canthidium aff. angusticeps Bates*

Canthidium aff. gigas Balthasar

Canthidium aff. guyanense Boucomont

Canthidium aff. onitoides (Perty)*

Canthidium aff. ruficolle Germar

Canthidium aff. trinodosum Boheman*

Canthidium aff. viride (Lucas)*

Canthidium deyrollei Harold

Canthidium dohrni Harold

Canthidium gerstaeckeri Harold

Canthidium gracilipes Harold*

Canthidium latipleurum de Borre*

Canthidium quadridens Harold*

Canthidium sp. 1*

Canthidium sp. 2*

Canthidium sp. 3*

Canthidium sp. 4

Canthidium sp. $5^{\circ}$

Canthidium sp. 6

Canthidium sp. 7*

Canthidium sp. 8*

Canthidium sp. 9

Canthon semiopacus Harold

\begin{tabular}{|c|c|c|c|c|c|c|c|c|c|c|c|c|c|c|c|}
\hline \multicolumn{8}{|c|}{2003} & \multicolumn{8}{|c|}{2004} \\
\hline \multicolumn{4}{|c|}{ FIT } & \multicolumn{4}{|c|}{ Pitfall } & \multicolumn{4}{|c|}{ FIT } & \multicolumn{4}{|c|}{ Pitfall } \\
\hline C & $\mathrm{P}$ & I & $\mathrm{T}$ & $\mathrm{C}$ & $\mathrm{P}$ & I & $\mathrm{T}$ & $\mathrm{C}$ & $\mathrm{P}$ & I & $\mathrm{T}$ & $\mathrm{C}$ & $\mathrm{P}$ & I & $\mathrm{T}$ \\
\hline & & & & 2 & & 2 & & & & & & 1 & & 1 & \\
\hline
\end{tabular}

2

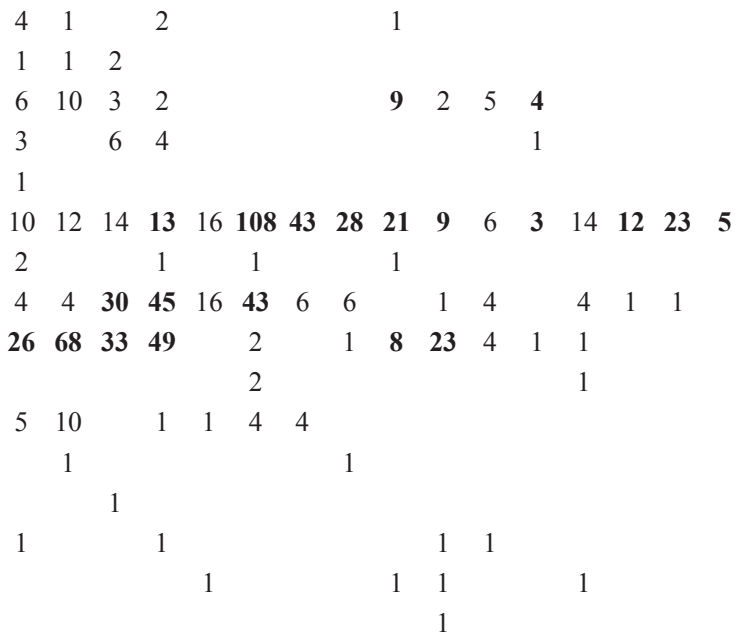

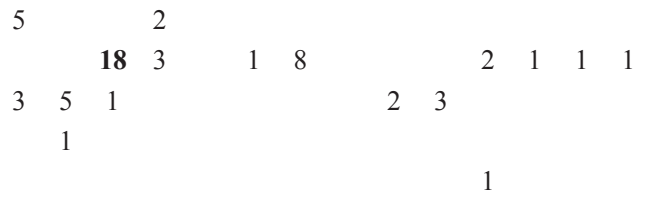

1

$\begin{array}{lllllllll}7 & 12 & 1 & 1 & 1 & 7 & 1 & 7 & 1\end{array}$

1

$\begin{array}{llllll}11 & 5 & 2 & 3 & 1 & \mathbf{1 0}\end{array}$

$\begin{array}{llllllllll}5 & 1 & 5 & 1 & 1 & 2 & 1 & & 3 & 1\end{array}$

$\begin{array}{lllllllll}1 & 2 & 4 & 3 & 3 & 1 & 4 & 1 & 3\end{array}$

$\begin{array}{lllllll}7 & 7 & 35 & 13 & 3 & 7 & 19\end{array}$

$\begin{array}{lllllll}11 & 21 & 2 & 3 & 3 & 4 & 2\end{array}$

$23 \quad 1101$

$1 \quad 1$

$\begin{array}{llll}1 & 2 & 1 & 2\end{array}$

$\begin{array}{llll}2 & 2 & 2 & 2\end{array}$

$\begin{array}{llll}3 & 3 & 1\end{array}$

$\begin{array}{lllllll}3 & 8 & 4 & 2 & 1 & 2 & 3\end{array}$

$\begin{array}{lllll}2 & 6 & 1 & 2 & 2\end{array}$

3

$3 \quad 1$

311


APPENDIX (Continued)

List of the dung beetle species collected in pitfall traps and FITs in four sites in Nouragues Natural Reserve. Species with abundance $\geq 5 \%$ of total sample are underlined. Creek: C, Plateau: P, Inselberg: I, Terrace: T.

\begin{tabular}{|c|c|c|c|c|c|c|c|c|c|c|c|c|c|c|c|c|}
\hline \multirow{3}{*}{ Species } & \multicolumn{8}{|c|}{2003} & \multicolumn{8}{|c|}{2004} \\
\hline & \multicolumn{4}{|c|}{ FIT } & \multicolumn{4}{|c|}{ Pitfall } & \multicolumn{4}{|c|}{ FIT } & \multicolumn{4}{|c|}{ Pitfall } \\
\hline & $\mathrm{C}$ & $\mathrm{P}$ & I & $\mathrm{T}$ & $\mathrm{C}$ & $\mathrm{P}$ & I & $\mathrm{T}$ & $\mathrm{C}$ & $\mathrm{P}$ & I & $\mathrm{T}$ & $\mathrm{C}$ & $\mathrm{P}$ & I & $\mathrm{T}$ \\
\hline Canthon bicolor Castelnau & 3 & 3 & 1 & 2 & 21 & 116 & & 5 & & 8 & 1 & & 8 & 25 & 2 & 7 \\
\hline Canthon aff. sericatus Schmidt* & 2 & 5 & 3 & 2 & & & & & & 1 & 2 & & & & & \\
\hline Canthon triangularis (Drury) ${ }^{\circ}$ & & & & & & & & & & & & & & & 5 & \\
\hline Canthonella sp. 1 & 1 & & & & & & & & & & & & & & & \\
\hline Coprophanaeus lancifer (Linné) & & 3 & 5 & 8 & 1 & & & & & & 5 & 1 & & & & \\
\hline Coprophanaeus christophorowi Olsoufieff* & 4 & & 1 & & & & & & & & 2 & & & & & \\
\hline Coprophanaeus dardanus Mac Leay & & 1 & & 3 & 4 & & & & & & 3 & 1 & & & & \\
\hline Coprophanaeus jasius (Olivier) & 2 & 4 & & 3 & 1 & & & & & & 2 & & & & 1 & \\
\hline Coprophanaeus parvulus Olsoufieff & 4 & 1 & & 2 & & & 3 & & & & 3 & & & & & \\
\hline Deltochilum carinatum (Westwood) & & 3 & 5 & 1 & & 1 & 3 & & & 1 & 1 & & & 2 & & 1 \\
\hline Deltochilum guyanense Paulian & 39 & 7 & 11 & & 13 & 3 & 6 & & 21 & & 7 & 1 & 4 & 4 & 2 & \\
\hline Deltochilum icarus (Olivier) & & & 4 & & 1 & 2 & & & & & 5 & & & & 1 & 1 \\
\hline Deltochilum orbiculare Van Lansberge ${ }^{\circ}$ & & & & & & & & & & & & & & 1 & & \\
\hline Deltochilum septemstriatum Paulian & 2 & & & & & & & & 1 & & & & 1 & & & \\
\hline Deltochilum submetallicum (Castelnau) & 1 & 1 & 17 & & 5 & 11 & 8 & 1 & & 1 & 5 & & 1 & 9 & 18 & 3 \\
\hline Deltochilum aff. valgum Burmeister* & 3 & 1 & 4 & 1 & & & & & & & 1 & 1 & & & & \\
\hline Dendropaemon aff ater Castelnau* & & & 1 & & & & & & & & & & & & & \\
\hline Dichotomius apicalis Luederwaldt & & & 4 & & 1 & 5 & 1 & & & & 1 & & 1 & & 1 & \\
\hline Dichotomius boreus (Olivier) & & 1 & 3 & 1 & 8 & 55 & 3 & 1 & 1 & 1 & 1 & & 23 & 14 & 5 & 3 \\
\hline Dichotomius sp. $1^{*}$ & & 2 & & & & & & & 2 & 7 & & & & & & \\
\hline Dichotomius robustus (Luederwaldt) ${ }^{\circ}$ & & & & & 2 & & & & & & & & 5 & & & 1 \\
\hline Dichotomius lucasi (Harold) & & 7 & 53 & & 17 & 15 & 24 & 3 & & & 10 & 1 & 6 & 2 & 12 & \\
\hline Dichotomius subaeneus (Castelnau) & & 3 & & & 7 & 11 & & & & & & & 3 & 3 & & \\
\hline Eurysternus balachowskyi G. Halffter and V. Halffter* & 1 & & & & & & & & & & & & & & & \\
\hline Eurysternus caribaeus (Herbst) & 4 & 3 & & 1 & 2 & 29 & 2 & 4 & 1 & & 1 & 2 & 7 & & & \\
\hline Eurysternus cayennensis Castelnau & 2 & 3 & 26 & 6 & 14 & 6 & 13 & 3 & & 1 & 17 & 1 & 1 & 11 & 19 & 1 \\
\hline Eurysternusvastiorum Martinez & 3 & 4 & & 11 & 13 & 25 & 5 & 5 & 1 & 1 & 1 & & 5 & 15 & 1 & 5 \\
\hline Eurysternus foedus Guérin-Méneville & & 1 & 1 & 4 & & & 1 & 2 & & & & & & & & 1 \\
\hline Eurysternus hamaticollis Balthasar ${ }^{\circ}$ & & & & & 1 & & & & & & & & & & & \\
\hline Eurysternus aff. cambeforti Genier & & 1 & & 1 & 2 & 3 & 2 & & 2 & & & 1 & & 1 & & 2 \\
\hline Eurysternus velutinus Bates & 1 & & & 2 & 12 & 13 & & & & & & & 8 & 1 & & 2 \\
\hline Glaphyrocanthon quadriguttatus (Olivier) & & 2 & 4 & & & & 1 & 3 & & & 1 & 1 & & & & \\
\hline Glaphyrocanthon subcyaneus Erichson* & & & & 1 & & & & & & & & & & & & \\
\hline Hansreia affinis (Fabricius) & 4 & & 3 & & 150 & 112 & 164 & 4 & 2 & 1 & & 1 & 30 & 43 & 171 & 5 \\
\hline Onthophagus haematopus Harold $^{\circ}$ & & & & & & & & & & & & & & & 1 & \\
\hline Onthophagus rubrescens Blanchard & 3 & 4 & 3 & & 69 & 109 & 40 & 13 & & & 2 & & 43 & 28 & 22 & 1 \\
\hline Onthophagus xanthomerus Bates $^{\circ}$ & & & & & 15 & & & & & & & & 2 & 1 & & \\
\hline Oxysternon spiniferum Castelnau* & 4 & & 2 & & & & & & 2 & & & & & & & \\
\hline Oxysternon durantoni Arnaud & 4 & 5 & & 3 & 32 & 29 & 8 & 5 & 4 & & 2 & & 7 & 20 & 10 & \\
\hline Oxysternon festivum (Linné) & 3 & & 13 & 3 & 81 & 29 & 14 & 4 & 4 & & & & 45 & 14 & 16 & 1 \\
\hline Oxysternon silenus Castelnau $^{\circ}$ & & & & & & 1 & & & & & & & 1 & & & \\
\hline Phanaeus bispinus Bates* & & & & & & & & & 1 & & & & & & & \\
\hline Phanaeus cambeforti Arnaud $^{\circ}$ & & & & & 1 & 4 & 1 & & & & & & 1 & & & \\
\hline
\end{tabular}


APPENDIX (Continued)

List of the dung beetle species collected in pitfall traps and FITs in four sites in Nouragues Natural Reserve. Species with abundance $\geq 5 \%$ of total sample are underlined. Creek: C, Plateau: P, Inselberg: I, Terrace: T.

\begin{tabular}{|c|c|c|c|c|c|c|c|c|c|c|c|c|c|c|c|c|}
\hline \multirow{3}{*}{ Species } & \multicolumn{8}{|c|}{2003} & \multicolumn{8}{|c|}{2004} \\
\hline & \multicolumn{4}{|c|}{ FIT } & \multicolumn{4}{|c|}{ Pitfall } & \multicolumn{4}{|c|}{ FIT } & \multicolumn{4}{|c|}{ Pitfall } \\
\hline & $\mathrm{C}$ & $\mathrm{P}$ & I & $\mathrm{T}$ & $\mathrm{C}$ & $P$ & I & $\mathrm{T}$ & $\mathrm{C}$ & $\mathrm{P}$ & I & $\mathrm{T}$ & $\mathrm{C}$ & $\mathrm{P}$ & I & $\mathrm{T}$ \\
\hline Phanaeus chalcomelas (Perty) & 3 & 1 & & 2 & 1 & 1 & & 5 & 2 & & & & 2 & 4 & 4 & \\
\hline Scybalocanthon pygidialis (Schmidt) & 3 & 3 & & & & 14 & 4 & & & & & & & 6 & 2 & \\
\hline Sulcophanaeus faunus (Fabricius) ${ }^{\circ}$ & & & & & 1 & & 1 & & & & & & & & & \\
\hline Sylvicanthon candezei (Harold) & & 1 & & & 1 & 16 & & & 1 & 1 & & & & & & \\
\hline Tetramereia convexa (Harold)* & & 1 & 1 & & & & & & & & 1 & & & & & \\
\hline Trichocanthon sordidus Harold & 4 & 19 & 15 & 26 & 29 & 27 & 6 & 28 & 3 & 5 & 20 & 4 & 30 & 17 & 12 & 17 \\
\hline Uroxys sp. 1 & 1 & & 2 & 1 & 1 & & & & & & 1 & & & & & \\
\hline Uroxys sp. 2 & & 7 & 1 & 4 & 23 & 7 & & & 1 & 1 & 1 & 1 & 1 & & & \\
\hline Uroxys sp. 3 & 6 & 2 & 2 & & 22 & 27 & 1 & 1 & 2 & 2 & & & 5 & 4 & 1 & 1 \\
\hline Ateuchini undetermined* & 2 & 2 & 1 & 1 & & & & & 2 & & & & & & & \\
\hline
\end{tabular}

- Species exclusive to pitfall sample.

* Species exclusive to FIT sample. 